DOI: $10.21580 /$ ihya.17.1.1733

\title{
KARAKTER HUBUNGAN DAN HARMONISASI KEHIDUPAN ANTARA KELOMPOK KEAGAMAAN RIFA'IYAH DAN NU
}

\author{
Dandung Budi Yuwono \\ Lembaga Penelitian Universitas Islam Negeri (UIN) Sunan Kalijaga Yogjakarta \\ E-mail: dandungyuwono@yahoo.com
}

\begin{abstract}
This research is to reveal the socio-religious conflicts that have been occurred between the religious group of Rifa'iyah and NU (Nahdlatul Ulama). The result of this research showed that economic competition has resulted in social conflicts and tensions. There has been a sensitive relation between religious groups of Rifa'iyah and NU. In ordert to create and keep a harmony, both need various activities that include togetherness between Rifa'iyah and NU as a social cohesion. In the future, religious spirit and 'corporate culture' is a model how to develop a harmony, which can provides support for preventing conflict. This research is classified as qualitative research. The data in this research is collected using three of data collection techniques, namely observation, participative observation, and indepth-interview. The analysis data used in this research is triangulation analysis techniques with attention to emic and ethic perspective.
\end{abstract}

Key words: Harmonization; Relationship characters; Religious Groups

\begin{abstract}
ABSTRAK
Penelitian ini bertujuan untuk mengungkap konflik sosio-religius yang terjadi antara kelompok keagamaan Rifa'iyah dan NU (Nahdlatul Ulama). Hasil penelitian ini menunjukkan bahwa persaingan ekonomi telah mengakibatkan konflik sosial dan ketegangan di antara dua kelompok tersebut. Terdapat hubungan sensitif antara kelompok agama Rifa'iyah dan NU. Dalam rangka menciptakan dan menjaga harmoni, keduanya membutuhkan berbagai kegiatan yang mencakup kebersamaan antara Rifa'iyah dan NU sebagai sebuah kohesi sosial.
\end{abstract}


Ke depan, semangat religius dan 'budaya perusahaan' adalah model bagaimana mengembangkan harmoni, yang bisa memberi dukungan untuk mencegah konflik. Penelitian ini diklasifikasikan sebagai penelitian kualitatif. Data dalam penelitian ini dikumpulkan dengan menggunakan tiga teknik pengumpulan data, yaitu observasi, observasi partisipatif, dan indepth-interview. Data analisis yang digunakan dalam penelitian ini adalah teknik analisis triangulasi dengan memperhatikan aspek emik dan etik.

Kata Kunci: Harmonisasi; Karakter Hubungan; Kelompok Keagamaan

\section{A. Pendahuluan}

Kelompok-kelompok keagamaan Islam dengan berbagai paham, aliran, dan karakter tidak berada dalam batas-batas fisik (physical boundaries) yang tegas. Keberadaannya satu sama lain telah bercampur dalam satu ruang fisik yang antar mereka telah membagi wilayah secara saling bersinggungan bahkan berhimpitan. Praksis paham ajaran dan gerakan keagamaan yang ditegaskan dan dipertukarkan dalam serangkaian interaksi, di satu sisi merupakan potensi yang membentuk identitas dan ciri-ciri pembeda satu dengan yang lain, dari persepsi, bentuk dan cara peribadatan, tradisi, cara bicara, perilaku hingga simbol-simbol atau atribut kelompok keagamaan. Di lain sisi, paham ajaran dan gerakan keagamaan merupakan faktor yang dapat memicu konflik sosial karena identitas dan ciri pembeda dapat digunakan secara sosial tidak hanya sebagai 'ciri pembeda' tetapi juga sebagai faktor 'pemisah' (eksklusi sosial) antara kelompok keagamaan satu dengan yang lain dalam suatu sistem sosial.

Rifa'iyah yang didirikan oleh KH. Ahmad Rifa'i adalah salah satu kelompok keagamaan Islam yang telah hadir sejak masa penjajahan Belanda pada paro pertengahan abad ke-19. Secara historis latar belakang kemunculan gerakan Rifa'iyah bukan semata-mata merupakan gerakan protes terhadap kolonialisme. Tetapi merupakan gerakan agama tradisional yang pemikiran dan gerakannya mampu memunculkan gerakan keagamaan yang memiliki andil dalam pengajaran Islam, bercorak induktif, menghubungkan antara norma dan kenyataan sosial: berangkat dari fenomena sosial yang dikaitkan dengan al-Qur'an, hadits, dan pandangan ulama. Praktis pemikirannya banyak mencampuri urusan di luar ibadah mahdhoh, yang terlihat begitu rinci mengupas berbagai 
masalah masyarakat yang timbul saat itu, dikenal kritis dan tidak mengenal kompromi dengan pemerintah kolonial Belanda (Abdul Djamil, 2001: ix). Itu sebabnya pemerintah kolonial menstigmasi gerakan Rifa'iyah sebagai ajaran 'sesat'. Untuk terus dapat melangsungkan ajaran Kiai Ahmad Rifa'i sekaligus sebagai ekspresi ketidaksetujuan atas hadirnya elite kekuasaan yang tidak islami, banyak di antara warga Rifa'iyah kemudian mengisolasi diri dari 'kebudayaan kota', berkonsentrasi di wilayah pedesaan. Meski kurang berhasil mengubah keadaan, namun kemunculan pemikiran dan gerakan Rifa'iyah merupakan simbol gerakan kebudayaan tradisional anti kekuasaan.

Tidak ada perbedaan mendasar antara pandangan Kiai Rifa'i dengan kitab-kitab fiqh di dunia pesantren, hanya penerapannya lebih fokus pada aspek yang relevan dengan suasana keagamaan di tengah kekuasaan Belanda abad ke-19. Premis rumusan 'ahlussunnah' yang dikedepankan Kiai Rifa'i pun secara substansial sama sebagaimana pemikiran di kalangan Nahdlatul Ulama (NU) dan pemikiran Kiai Rifa'i menjadi kecenderungannya. Kemunculan Rifa'iyah juga memiliki arti penting dilihat dari konteks komunitas keagamaan di Indonesia setelah NU dan Muhammadiyah.

Tetapi jika dilihat hubungannya dengan kelompok keagamaan Islam lainnya, khususnya dengan kelompok NU, mengandung unsur-unsur kontroversial karena persoalan substansi keyakinannya yang berbeda: Rifa'iyah memandang Rukun Islam hanya ditopang oleh satu unsur utama (rukun) yakni 'syahadat'. Perbedaan demikian memunculkan sikap pro dan kontra, dan menjadi perdebatan di kalangan komunitas agama. Sebagian memahami perbedaan itu hanya pada tataran definisi (lafdhi) bukan secara maknawi (makna) yang tidak perlu dipersoalkan (Hasbullah, 2008: 13). Sebagian lain memandang bahwa antara rukun satu dan lainnya merupakan kesatuan. Jika hanya menekankan pada unsur 'syahadat' maka Rukun Islam akan kehilangan makna sebagai bangunan Islam. Bisa jadi sejak kemunculan kontroversi ini telah dibarengi, menyimpan, dan memiliki potensi konflik di antara mereka sekalipun bersifat terselubung (hidden conflict), sehingga tidak terlampau keliru jika awam memandang bahwa aktualisasi hubungan antara kelompok Rifa'iyah dengan kelompok NU mengalami 'gangguan' harmonisasi meski bertipologi sama. 
Ada dua persoalan mendasar yang dihadapi kelompok Rifa'iyah di tengah kelompok keagamaan Islam. Pertama, meski kemunculan gerakan Rifa'iyah mengandung unsur-unsur perjuangan terhadap kolonialisme namun setelah merdeka justru menghadapi masalah dengan kelompok Islam lainnya. Seberapa jauh kecurigaan itu berlangsung akan sangat tergantung pada usaha yang dilakukan kelompok Rifa'iyah untuk memberi penjelasan tentang ajaran Kiai Rifa'i dan sikap demokratis yang ditunjukkan oleh komunitas agama. Kedua, secara obyektif, di satu sisi Rifa'iyah telah berkembang di beberapa wilayah di Indonesia (Abdul Djamil: 192-206), tetapi di lain sisi, ia terus mengalami tekanan struktural.

Namun realitas di dalam praktik kehidupan, antara kelompok Rifa'iyah dan kelompok NU di beberapa wilayah dapat berlangsung harmonis dan dapat berinteraksi sosial secara baik, yang dipertegas dengan belum adanya fakta yang mampu menjelaskan adanya konflik antara kedua kelompok agama tersebut. Pertanyaannya, benarkah secara obyektif antara kelompok Rifa'iyah dan kelompok NU tidak pernah mengalami konflik? Jika pernah, mengapa mereka berkonflik dan bagaimana proses terwujudnya harmonisasi hubungan di antara mereka, dan kembali mempertanyakan bagaimana proses dialektika yang mensyaratkan dan melibatkan berbagai daya dukung baik aspek sosial, budaya, dan peran tokoh-tokoh agama berlangsung? Untuk itu, pertanyaan relevan sebagai rumusan masalah dalam penelitian ini, yakni: (1) Bagaimana karakter hubungan antara kelompok Rifa'iyah dengan kelompok NU?; (2) Bagaimana mereka membangun harmonisasi kehidupan?; dan, (3) Model hubungan seperti apa yang tahan terhadap benturan konflik dan yang dapat bertahan lama?

\section{B. Pembahasan}

\section{Konsep Artikulasi}

Penelitian ini merupakan penelitian kualitatif, yang metode pengumpulan datanya menggunakan teknik pengamatan (observasation) dan pengamatan terlibat (observation participation), serta wawancara mendalam (indepth interview). Teknik pengamatan digunakan untuk menentukan subyek penelitian tingkat individual dan subyek penelitian tingkat komunitas (kelompok kegamaan Islam). Tindakan pengamatan 
kemudian dilanjutkan dengan pengamatan terlibat baik pada tingkat individu (warga) maupun tingkat kelompok pada masing-masing kelompok keagamaan Islam di wilayah penelitian yang dilakukan dengan cara membangun hubungan baik terhadap masing-masing warga kelompok keagamaan Islam. Untuk melengkapi data pengamatan terlibat dilakukan pula wawancara mendalam pada tingkat individu (warga jamaah) maupun komunitas (kelompok-kelompok keagamaan). Pengumpulan data melalui wawancara pada tingkat individual dilakukan terhadap subyek penelitian yang terpilih untuk mengetahui etika lokal dan bagaimana mereka (dalam hal ini kelompok Rifa'iyah dengan kelompok NU) mereproduksi hubungan di masa lalu dan kekinian. Sedang wawancara pada tingkat komunitas dilakukan untuk mengumpulkan data tentang gambaran sosial budaya yang dijadikan setting wilayah penelitian.

Semua data hasil wawancara dan pengamatan dicatat secara cermat, serinci mungkin dan dikumpulkan sehingga menjadi suatu catatan lapangan atau fieldnotes. Selanjutnya semua data yang diperoleh kemudian dianalisis secara kualitatif yang akan menghasilkan thick description dengan memperhatikan perspektif emik dan etik.

Hasil penelitian ditampilkan dalam bentuk analisis deskriptif (interpretif) dengan melibatkan tahap-tahap teknik triangulasi. Sesuai dengan kaidah analisis triangulasi, data yang diperoleh dari informan akan dianalisis secara terus menerus selama proses pengumpulan data di lapangan berlangsung (Burhan Bungin, 2003: 100). Tahapan analisisnya adalah data dan informasi yang diperoleh dikelompok-kelompokan menurut kriteria-kriteria yang berkaitan dengan permasalahan penelitian yang mengacu pada konsep atau teori yang digunakan (Burhan Bungin:64). Data dan informasi tersebut diklasifikasikan dan dipilah-pilah ke dalam satuan-satuan yang sesuai dengan tujuan penelitian. Geertz menyebut tahapan ini dengan istilah diagnosis terhadap tindakan-tindakan simbolis. Setelah diklasifikasi, data yang telah terspesifikasi tersebut selanjutnya diabstraksi, diinterpretasi serta dihubungkan antara satu dengan lainnya, sehingga melahirkan dugaan baru mengenai kenyataan-kenyataan yang ditelusuri (Clifford Geertz, 1992: 33). Hasil dugaan tersebut kemudian diperbandingkan dengan fakta yang diperoleh dari wawancara dan observasi, serta dokumen. 
Setelah diperbandingkan dilakukan pencarian relasi logis untuk menemukan konteks yang terbangun dari fakta yang diperbandingkan tersebut. Dengan meminjam istilah Geertz, konteks yang terbangun tersebut merupakan aliran perbincangan sosial yang diperoleh dari hasil menerka-nerka makna, dan menaksir ulang terkaan tersebut untuk menemukan kesimpulan eksplanatoris dari terkaan yang lebih baik. Pada tahap inilah analisis interpretif dapat diakhiri dan penyajian tulisan etnografi dimulai.

\section{Selintas Tentang Desa Paesan Tengah, Kedungwuni Barat, Pekalongan}

Desa Paesan Tengah, Kecamatan Kedungwuni Barat, Kabupaten Pekalongan merupakan wilayah pemukiman warga Rifa'iyah terbesar di Pekalongan, terletak di sebelah barat daya Kota Pekalongan yang berjarak kurang lebih 9 kilometer dari pusat kota. Umumnya warga di kalangan Rifa'iyah (baik di luar maupun di dalam wilayah Pekalongan) menyebut wilayah ini cukup dengan sebutan Paesan (selanjutnya dalam tulisan ini pun setiap menyebut Desa Paesan Tengah ditulis dengan Paesan).

Kehadiran warga Rifa'iyah di Paesan cukup memberi arti dan nilai bagi wilayah ini. Warga Rifai'iyah yang mayoritas bergerak di sektor industri kerajinan konveksi dapat memajukan dan menjadikan wilayah Paesan sebagai salah satu sentra konveksi di Pekalongan. Majunya pesantren kelompok Rifa'iyah pun menjadi daya tarik para santri dari berbagai penjuru yang datang untuk belajar di Pondok Paesan, sehingga wilayah ini semakin dikenal masyarakat luas, ramai, dan dinamis. Di lain pihak, akibat pemekaran kota, semakin menjadikan wilayah Paesan sebagai kawasan yang ramai, padat dengan berbagai aktivitas perdagangan dan bisnis. Sepanjang jalan dari arah kota menuju Paesan telah dipadati berbagai bangunan rumah penduduk dan tersedianya berbagai fasilitas umum, seperti, pasar, pusat pertokoan dan berbagai tempat usaha, sekolahan, perbankan, rumah sakit, hotel dan penginapan hingga sarana transportasi umum. Praktis, pemukiman warga kelompok Rifa'iyah di Paesan seolah tidak lagi berada di lingkungan pedesaan, karena telah menyatu dengan pusat kota Pekalongan. 


\section{Kehidupan Warga Paesan: Perspektif Agama dan Sosio-Kultural}

"Ya rasulallah salamun alaik.. Ya rafíasy-syani wad-daroji.. 'Ath'fata ya jiratal 'alami.. Ya uhailaljuu di wal karomi..."

Lantunan penggalan sholawat di atas yang sesekali disisipi lirik-lirik berbahasa Jawa (singiran) tak henti-hentinya menggema di masjid-masjid Paesan. Beberapa kegiatan, seperti, tadarus al-Qur'an, khataman kitab Tarajumah bagi anak-anak, takjilan menjelang buka puasa pun berlangsung di mushola dan di masjid-masjid menjadikan atmosfer wilayah ini terasa begitu islami dan sakral. Banyaknya para santri dari luar wilayah Paesan yang datang untuk belajar 'ngaji' kitab-kitab Tarajumah, al-Qur'an, tafsir al-Qur'an dan hadits, serta fiqh pun menambah semaraknya suasana. Inilah yang dapat ditangkap secara inderawi dan dapat dirasakan pada saat kali pertama peneliti memasuki wilayah Paesan. Bukan karena saat penelitian berlangsung umat muslim sedang melaksanakan ibadah puasa Ramadlan $1433 \mathrm{H}$, tetapi memang intensitas peribadatan masyarakat Paesan begitu menonjol. Masjid dan mushola telah menjadi bagian ruang kultural kehidupan masyarakat Paesan, yang fungsinya tidak hanya sebatas ruang peribadatan tetapi menjadi pusat kegiatan sosial dan center of excellent.

Meski masyarakat Paesan terbingkai dalam kelompok-kelompok agama namun mereka satu sama lain dapat hidup saling rukun (harmonis). Secara kuantitas kelompok Rifa'iyah adalah kelompok terkecil dibanding kelompok NU dan Muhammadiyah. Populasi warga Rifa'iyah di Paesan berjumlah tidak lebih dari 1000 orang (terdiri atas $150 \mathrm{KK}$ ) yang tersebar di 4 RT dalam 2 RW. Sekalipun berpopulasi relatif kecil, kelompok Rifa'iyah Paesan adalah kiblat bagi warga Rifa'iyah lain, di luar Paesan. Hal ini karena selain masih terdapat kiai-kiai sepuh, warga Rifa'iyah Paesan relatif masih (istiqomah) memegang teguh (taqlid) ajaran Kiai Rifa'i disegala aspek kehidupan, dan terus melakukan reproduksi ajaran Kiai Rifa'i dengan mempelajari kitab-kitab Tarajumah, menanamkan dan mengajarkan kepada generasi penerus sejak usia dini.

Masyarakat Paesan nyaris tidak mengenal tradisi sebagaimana masyarakat Jawa pedalaman, seperti ngapem, upacara adat tradisional dalam perkawinan, sesaji, dan sebagainya. Namun demikian bukan berarti mereka anti tradisi budaya Jawa, dan mudah mengatakan (menilai) 'syirik', 
'musyrik', 'bid'ah' terhadap masyarakat yang melakukan penyimpangan nilai-nilai ajaran Islam. Bagi warga Rifa'iyah, orang dikatakan bid'ah jika ia nyebal (menyimpang) dari empat pedoman, yakni al-Qur'an, hadist, ijma' dan qiyas. Di lain pihak, warga kelompok Muhammadiyah tidak menentang ritual seperti tahlil, sholawat, manaqiban, perayaan maulid, qunut, atau ziarah kubur sebagaimana dilakukan warga NU maupun Rifa'iyah. Dapat saling memahami dan saling menghargai perbedaan demikian mencerminkan sikap kedewasaan masyarakat di Paesan dalam beragama.

Begitu ketat dan taatnya warga Rifa'iyah dalam beribadah sehingga oleh warga kelompok NU mereka disebut sebagai kelompok 'ghoiru' atau kelompok 'mbud' (dari kata budiyah), sebab: pertama, di dalam ajaran Rifa'iyah mengenal dosa kecil dan dosa besar. Karenanya, orientasi aktivitas dalam kehidupan sehari-hari tidak lepas dari peribadatan, dan menghindarkan diri dari perbuatan dosa sekalipun dalam ketegori dosa kecil. Kedua, dalam hal sholat, warga Rifa'iyah memiliki aturan ketat dan sangat memperhatikan syarat dan rukun, utamanya gerakan sholat. Karenanya, warga Rifa'iyah jarang menunaikan sholat berjamaah, termasuk sholat Jum'at yang diimami oleh orang di luar kelompok mereka. Alasannya, jika gerakan sholat imam tidak benar (istilah mereka: ora madal), maka sholat yang didirikan tidak sah, yang berarti batal. Mereka mengatakan bersifat dharurat (situasional) manakala harus berjamaah (sholat Jum'at) di luar kelompoknya. Konsekuensi logisnya, warga Rifa'iyah tidak dapat hidup di luar kelompoknya. Domisili dan pola tinggal warga Rifa'iyah di manapun dilakukan secara berkelompok dengan memiliki masjid sendiri yang berciri khas. Meski mereka dapat hidup rukun secara sosial bersama warga kelompok lain, tetapi 'tidak' dan 'bukan' dalam urusan peribadatan (sholat). Masjid Rifa'iyah terbuka bagi warga kelompok lain, tetapi tegas bahwa kelompok Rifa'iyah tidak akan mungkin bergabung dengan kelompok lain di masjid yang bukan milik kelompoknya.

Di bagian lain, warga Rifa'iyah dikenal beretos kerja tinggi dalam mencari nafkah dan sangat memegang teguh ajaran mursyid-nya, Syaikh Ahmad Rifa'i, yakni: "Sekedar kuat kanggo tulung ibadah lan sangu akherat". Mereka sangat hati-hati dalam mencari nafkah dan tidak 'ngoyo' (qona'ah). Dipilihnya usaha konveksi sebagai fokus mata pencaharian karena dipandang sebagai usaha yang 'halal' dan 'thoyyib', materi bahan bakunya 
jelas tidak menyimpang dari tuntunan agama. Berbeda dengan jual-beli emas (kemasan). Menurut mereka kadar emas tidak sepenuhnya adalah murni emas, tetapi tercampuri material lain, seperti timbal (plumbum) yang dapat memperberat timbangan. Atas pemikiran yang demikian sehingga warga Rifa'iyah ekstra hati-hati (subhat) dan selektif dalam berdagang. Sementara ajaran Kiai Rifa'i, "luwih becik wong nandur telo kasab tangane, tinimbang melu londo" (lebih baik orang menanam ketela meski menjadikan kasar tangannya daripada harus bekerja ikut Belanda) tentang kemandirian mencari nafkah dan agar tidak bekerja untuk pemerintah kolonial adalah konteks masa lalu, namun kenyataannya ajaran ini terus direproduksi dalam praktik kehidupan kekinian. Itu sebabnya, menjadi PNS bukan cita-cita warga Rifa'iyah. Pandangan mereka PNS adalah bagian dari sistem pemerintahan yang selama ini dianggap $\mathrm{dzalim}$.

\section{Konflik dan Karakter Hubungan Rifa'iyah - NU}

Secara historis, warga Rifa'iyah hadir di Paesan diperkirakan sekitar tahun 1950 setelah lebih dahulu kelompok NU muncul dan berkembang di wilayah ini, yang mana antara warga Rifa'iyah satu sama lain masih mempunyai hubungan darah (klan). Sebagaimana pengakuan beberapa warga Paesan, sejak awal kehadirannya, warga Rifa'iyah memiliki semangat kerja tinggi, tidak mengenal lelah, dan saling bahu-membahu. Seiring perjalanan waktu dan atas kerja kerasnya, kehidupan mereka megalami peningkatan secara ekonomi, relatif mapan ketimbang warga kelompok NU. Namun persoalannya, sebagai warga baru yang hadir di tengah warga NU yang telah lebih dahulu menetap di Paesan sedang di antara mereka terdapat perbedaan ekonomi cukup mencolok, wajar jika kemudian muncul gesekan di antara mereka. Sementara konflik yang terjadi antara kelompok Rifa'iyah dan NU realitasnya telah dikonstruksi secara sosial, dihadirkan di tengah masyarakat yang dipahami sebagai konflik karena persoalan agama. Tidak dipungkiri, akibat perbedaan substansi keyakinan di antara kedua kelompok berpotensi konflik yang berdampak pada konstelasi hubungan mereka. Pertanyaannya, mengapa konflik tidak terjadi terhadap warga Muhammadiyah yang notabene bermadzhab berbeda dengan kelompok Rifa'iyah dan NU? 
Hampir dapat dipastikan, konflik tidak terjadi dengan kelompok Muhammadiyah selain adalah kelompok yang hadir belakangan, karena dalam bermatapencaharian antar mereka tidak mempunyai relevansi kepentingan, dimana mayoritas warga Muhammadiyah cenderung berprofesi sebagai pegawai negeri, pegawai swasta, dan guru (baca: bukan pedagang). Ini membuktikan bahwa konflik yang terjadi di Paesan bukanlah semata-mata karena persoalan agama, melainkan lebih kepada persoalan ekonomi. Gambaran ini semakin memperjelas, meski saat ini antara kelompok Rifa'iyah dan NU dapat hidup rukun (harmonis) tetapi di antara mereka sesungguhnya memiliki karakter hubungan yang 'sensitif'. Hubungan ini akan merenggang manakala warga kelompok Rifa'iyah terus melaju sementara warga kelompok NU tertinggal secara ekonomi. Karenanya, bagaimana mengelola konflik agar tidak kembali muncul dipermukaan adalah merupakan tugas warga kedua kelompok.

\section{Pengelolaan Konflik Menuju Harmonisasi: Mengedepankan Perspektif Internal dan Format Kegiatan Bersama}

Selama ini konflik yang terjadi antara kelompok Rifa'iyah dan NU lebih kepada konflik bathiniah yang hanya dapat dirasakan (hidden conflict), yang muncul dalam perkataan (misal, ejekan, fitnah, sindiran, dsb), sikap perilaku (misal, sabotase, non-kooperatif, egois tidak mau menerima pendapat orang lain, cara bicara, acuh tak acuh, dsb), dan simbol-simbol lain yang tidak sesuai dengan nilai-nilai agama, tidak sampai pada tataran pertikaian saling berhadap-hadapan secara fisik. Secara kualitatif hal demikian justru dirasakan sangat menganggu suasana kehidupan, yang jika dibiarkan akan semakin memperburuk hubungan antara warga Rifa'iyah dengan NU. Namun tidak jarang pula karena ulah oknum tertentu, antara generasi muda kelompok Rifa'iyah dan NU terlibat konflik yang dipicu oleh persoalan-persoalan 'sepele'. Tetapi agar tidak berkepanjangan dan tidak terjebak ke dalam konflik 'substansial', biasanya warga Rifa'iyah lebih memilih diam, tidak meladeni. Prinsip warga Rifa'iyah sekalipun berada pada pihak yang benar, tetapi jika meladeni yang salah maka juga akan menjadi salah. Mereka bisa meredam emosi, dan lebih baik 'meng-Allah' (istilah warga Rifa'iyah, yang bukan sekadar mengalah sebagaimana arti secara harfiah) karena mereka sadar bahwa konflik yang muncul tidak 
selamanya terbebas dari intervensi pihak ketiga di luar mereka. Inilah antara lain cara-cara yang selama ini dilakukan kelompok Rifa'iyah dalam mengelola konflik.

Menyikapi persoalan di atas, dikarenakan adanya keinginan ke luar dari persoalan konflik dan segera ingin mewujudkan harmomisasi hubungan antara warga Rifa'iyah dan NU, para elite agama (sesepuh) kedua kelompok melakukan dialog dan merencanakan serangkaian kegiatan bersama. Yang menarik dari upaya ini, yaitu adanya kesadaran di antara sesepuh agama yang memahami bahwa persoalan di Paesan adalah persoalan internal, sehingga strategi penyelesaiannya pun harus menggunakan strategi lokal dengan mengedepankan 'perspektif internal', yakni, sesuai dengan situasi dan kondisi masyarakat, sesuai kebutuhan dan keinginan mereka, sesuai kemampuan dan pengetahuan mereka, tidak terintimidasi dan diintervensi oleh pihak luar, dan satu sama lain wajib memegang teguh dengan apa yang telah menjadi keputusan dan kesepakatan bersama. Beberapa kegiatan yang telah dibangun melalui format bersama, yang dimaksudkan dapat menjadi perekat sosial, dan yang hingga kini masih terus dilakukan bersama, antara lain:

\section{a. Bidang Ekonomi Perdagangan}

Saat ini, mayoritas warga di Paesan (kecuali warga Muhammadiyah) bekerja dan bergerak di sektor usaha konveksi. Secara historis, menjamurnya usaha konveksi di wilayah ini, diawali dan dirintis lebih dahulu oleh warga kelompok Rifa'iyah. Manajemen usaha warga Rifa'iyah relatif baik dan maju, membuka jaringan pemasaran tidak saja di lingkup lokal Pekalongan tetapi hingga luar kota, bahkan luar Jawa. Peralatan yang dimiliki dan digunakannya pun termasuk canggih. Misal, untuk membuat lobang dan pemasangan kancing, bordir, pelabelan, dan packaging dilakukan dengan menggunakan peralatan mesin, komputer untuk desain, dan sebagainya. Masing-masing warga kelompok Rifa'iyah di Paesan telah memiliki semacam industri rumah tangga sendiri (home industry) dengan memiliki spesialisasi usaha atas dasar keahlian dan keterampilan.

Setiap produk yang dihasilkan hampir dapat dipastikan merupakan hasil kerja kolektif yang menggunakan konsep kemitraan. Ada keluarga yang usahanya khusus memasok bahan mentah, ada yang membuat desain dan pola baju, membuat lobang kancing dan memasangnya, 
membordir, menyetrika dan mengemas termasuk pemasangan label merk, dan sebagainya hingga yang hanya bergerak dalam jasa pengiriman. Di balik kemitraan usaha demikian selain menimbulkan semangat (ghiroh) kebersamaan, tidak ada hubungan 'patron-klien' (buruh-majikan), sehingga satu sama lain saling membutuhkan, lebih mempunyai tanggung jawab, dan setiap warga dapat memiliki kesempatan bekerja. Melalui caracara ini pula menjadikan perekonomian warga menjadi relatif merata, tidak hanya dikuasai oleh kalangan keluarga tertentu.

Dalam praktiknya, warga Rifa'iyah banyak melakukan hubungan kerja dengan warga kelompok NU, bersifat kemitraan di bidang usaha konveksi. Sebaliknya, sekalipun di kalangan warga NU ada yang telah mampu memiliki peralatan canggih dan mampu memproduksi secara mandiri tetapi mereka juga tetap menjalin kerjasama dengan warga Rifa'iyah. Cara-cara ini mampu memperlihatkan adanya corporate culture di antara mereka. Diakui beberapa sumber dari kalangan NU, bahwa semangat warga di kalangan NU untuk ikut ambil bagian bergerak dalam sektor usaha konveksi tidak lain karena ajakan warga kelompok Rifa'iyah. Dengan kata lain, signifikansi keberhasilan yang dicapai warga kelompok NU saat ini tidak lepas dari peran dan kontribusi warga Rifa'iyah, dari sejak bagaimana awal memulai, cara memasarkan produk hingga alih teknologi. Cara-cara yang dibangun oleh kelompok Rifa'iyah yang disambut baik oleh warga kelompok NU pada kenyataannya mampu menjalin harmonisasi hubungan di antara mereka.

\section{b. Bidang Pendidikan}

Di bidang pendidikan formal, baik kelompok Rifa'iyah, Muhammadiyah dan NU masing-masing telah memiliki lembaga pendidikan formal bernaung dalam sebuah yayasan. Saat ini, kelompok Muhammadiyah baru memiliki Madrasah TK (Raudlatul 'Athfal) dan Sekolah Dasar (Ibtidaiyah), sementara kelompok NU memiliki 2 Madrasah Ibtidaiyah (MI), yakni Wali Songo I dan II, yang baik murid dan staf pengajarnya banyak merekrut kelompok Rifa'iyah. Sedangkan kelompok Rifa'iyah memiliki Madrasah SLP atau Tsanawiyah (MTs) dan Madrasah SLA atau Aliyah (MA) yang khas, menggunakan konsep pondok, atau memisahkan antara Pondok Putra dan Pondok Putri. Karena jenjang 
pendidikannya yang lebih tinggi, banyak santri-santri pondok Rifa'iyah berasal dari luar lingkungan Paesan, bahkan dari luar Jawa.

Cukup lama warga Rifa'iyah ingin mendirikan Madrasah Ibtidaiyah (MI) dimaksudkan agar ada kesinambungan pengajaran (connected) sejak SD (MI) hingga SLA (MA). Sekalipun memiliki SDM dan fasilitas yang mumpuni, keinginan kuat tersebut terpatahkan oleh pemikiran Kiai Syandirin (almarhum, waktu itu menjabat sebagai Presiden Rifa'iyah), yang melarang pendirian MI. Dimaksudkan agar tidak 'merecoki' dengan apa yang telah menjadi wilayah garap dan yang telah dikembangkan warga kelompok NU. Bahkan keputusan tersebut tetap akan menjadi komitmen warga kelompok Rifa'iyah hingga kapan pun sepanjang kelompok NU masih memiliki MI. Hal demikian mencerminkan tingkat kepedulian warga Rifa'iyah terhadap arti pentingnya kebersamaan dan kerukunan hidup dalam satu lingkungan sosial. Hal demikian juga mampu menunjukkan adanya sikap arif, bijaksana, etika sosial, wawasan yang luas dan keseriusan warga Rifa'iyah dalam melakukan pengelolaan konflik demi tegaknya harmonisasi hubungan antarwarga di Paesan.

\section{c. Bidang Sosial dan Keagamaan}

Ada dua kegiatan besar yang ditetapkan sebagai agenda tahunan, yakni Peringatan Maulid Nabi Muhammad Saw. dan Isra' Mi'raj, dalam kemasan 'pengajian akbar dan gema sholawat'. Realitasnya, kegiatan ini dapat menjadi ajang kerjasama selama bertahun-tahun dan dapat mempererat hubungan antara warga Rifa'iyah dan NU. Dalam kegiatan ini telah pula diterapkan pembagian tugas dan disepakati bersama. Kelompok Rifa'iyah bertugas menghadirkan atau mencari penceramah (mau'idzoh khasanah) kiai-kiai besar berasal dari kelompok Rifa'iyah. Sementara kelompok NU bersama warga Rifa'iyah lain bertugas mempersiapkan segala sesuatu dalam mendukung acara tersebut, dari sejak persiapan hingga setelahnya. Mereka baur menjadi satu, saling bahu membahu, bergotong royong tanpa mempersoalkan siapa yang memprakarsai kegiatan tersebut. Dalam kegiatan tersebut mengundang dan juga dihadiri para jamaah lain dari luar warga Paesan, sehingga muncul istilah pedhut larut, karena ribuan jamaah tumpah ruah, tumplek bleg. Bahkan jamuan (makan dan snack) kepada ribuan jamaah yang hadir menjadi tanggung jawab bersama antara warga Rifa'iyah dan NU, mereka bershodaqoh tanpa 
itung-itungan. Selain kegiatan rutin tahunan ada pula yang bersifat harian, seperti haul, manaqiban, barzanjen, dan sebagainya yang dilaksanakan bersama dan bergantian.

\section{d. Bidang Pengembangan Ilmu Agama, Syiar, dan Seni}

Kegiatan dalam bidang pengembangan ilmu pengetahuan agama, seni dan syiar adalah kegiatan yang lebih ditiitikberatkan sebagai kegiatan pemuda Paesan. Forum yang disebut Malam Sabtunan, adalah salah satu forum dan arena silaturahmi para kawula muda kelompok Rifa'iyah dan NU. Kegiatan ini menjadi ajang diskusi dalam rangka penguatan dan memperkaya khasanah keilmuan agama berkisar persoalan aqidah, syariat, dan muamalah dalam konteks kekinian, di samping mempelajari teknik-teknik berdakwah (aspek komunikasi). Kegiatan semacam ini telah berjalan cukup lama yang hasilnya selain mampu memperkaya khasanah keilmuan agama, juga satu sama lain dapat semakin 'guyub'.

Dalam berkesenian, karena pemuda kelompok Rifa'iyah banyak yang memiliki keahlian dan telah memiliki grup seni 'terbangan' (yang oleh mereka disebut dengan 'jiduran') dengan tembang-tembang 'sholawat simtudduror' (duronan), maka merekapun menggetoktularkan kepada pemuda kelompok NU, dimaksudkan agar dapat lebih mencintai, merasa memiliki, melestarikan dan berkemampuan untuk memainkan alat-alat yang bernafaskan islam.

Beberapa hal yang telah diuraikan di atas dapat memberi gambaran bahwa Paesan merupakan sebuah lanskap sosio-kultural dan agama yang tidak terbebas dari adanya konflik antar kelompok agama. Gerakan protes dan fitnah yang diprovokasi warga kelompok NU (mayoritas) terhadap Rifa'iyah (minoritas) menjadi bukti bagaimanapun sebenarnya warga kelompok Rifa'iyah pada awalnya merasakan dan mengalami marjinalisasi. Sekalipun warga kelompok NU adalah kelompok mayoritas, tetapi ketertinggalan mereka secara ekonomi menjadi persoalan yang ingin dijelaskan melalui gerakan itu. Karenanya kasus Paesan menjadi sebuah fakta sosial yang dapat menjelaskan bahwa persaingan ekonomi menjadi titik awal dari konflik, yang terjadi pula di beberapa tempat di Indonesia.

Di bagian lain, sebagaimana dikatakan ahli-ahli sosial bahwa kelompok minoritas akan selalu berada dalam tekanan kelompok mayoritas, dan termarjinal. Tetapi tidaklah demikian yang terjadi di Paesan, 
bahkan fenomena di Paesan dapat memberikan antitesis dari pendapat para ahli ilmu sosial, dimana realitasnya kelompok Rifa'iyah sebagai minoritas mampu melakukan leading dalam segala sektor kehidupan atas kelompok lain, khususnya NU (mayoritas). Selain itu, kasus di Paesan meski mampu membuktikan masih adanya relevansi dengan teori yang dikembangkan oleh Bordieu yang ia sebut dengan field struggle yang kemudian dikonsepsikan dalam istilah disposition, bahwa orang akan dapat menguasai arena permainan sosial jika ia memiliki modal: kapital, simbol, sosial, dan kultur. Meskipun secara kapital (ekonomi) warga kelompok Rifa'iyah mampu melebihi kondisi warga kelompok NU, tetapi sekali lagi karena faktor relatif tingginya pemahaman agama dan taqlid terhadap ajaran Rifa'iyah maka hal demikian itu tidak terjadi di Paesan. Warga Rifa'iyah tidak serta merta melakukan penganiayaan secara sosial. Persoalan persaingan ekonomi dapat teratasi dengan baik antar mereka yang dapat dilihat sebagaimana gerakan kultural (corporate culture) yang dibuka lebar dalam bidang usaha konveksi.

\section{Simpulan}

Paesan sebagai sebuah entitas, kenyataannya di dalam kehidupan masyarakatnya penuh dengan dinamika persoalan dan berbagai perubahan dalam berbagai bentuk. Demikian halnya yang terjadi dalam konteks kehidupan antar kelompok keagamaan Islam yang merupakan bagian dari kehidupan masyarakat di wilayah ini. Sekalipun saat ini kehidupan antara kelompok keagamaan Rifa'iyah dan NU di wilayah Paesan tampak harmonis, bukan berarti di antara mereka nir-konflik. Kontroversi atas perbedaan substansi keyakinan yang terjadi antara kelompok Rifa'iyah dan NU realitasnya telah dikonstruksi secara sosial sebagai konflik bernuansa agama, sehingga antara mereka memiliki potensi konflik. Dengan dipicu adanya faktor kecemburuan sosial-ekonomi, potensi konflik tersebut memanifest ke dalam bentuk konflik sosial sekalipun bersifat bathiniah (hidden conflict). Dan, konflik akibat persaingan ekonomi telah memunculkan karakter hubungan yang 'sensitif' di antara kelompok Rifa'iyah dan NU. Artinya, meski saat ini hubungan antara kedua kelompok harmonis namun hubungan ini akan merenggang manakala warga kelompok Rifa'iyah semakin melaju secara ekonomi, sementara warga kelompok NU mengalami ketertinggalan. 
Potensi konflik dapat muncul kembali (manifest) ketika warga kedua kelompok tidak dapat membangun sekaligus mempertahankan harmonisasi hubungan atau lebih kepada bagaimana melakukan pengelolaan konflik dengan baik. Sebagai bentuk upaya mewujudkan itu semua, selama ini berbagai kegiatan sosial-keagamaan yang dibangun dengan format bersama, sesuai dengan situasi dan kondisi masyarakat, sesuai kebutuhan dan keinginan mereka, sesuai kemampuan dan pengetahuan mereka, cukup efektif dan mampu menjadi perekat sosial.

Namun, hal yang jauh lebih penting yang diperlukan dalam membangun sekaligus mempertahankan harmonisasi hubungan atau merupakan pengelolaan konflik di Paesan, yakni agar terus diupayakan semangat keberagamaan dan mempertahankan corporate culture, utamanya dalam bidang sosial-ekonomi mengingat warga antara kedua kelompok yang berkonflik memiliki 'paham agama' dan 'matapencaharian' berkarakter sama. Dengan cara yang sama, cara-cara atau model demikianlah yang diperlukan dalam membangun harmonisasi hubungan yang tahan terhadap benturan konflik antar kelompok agama dan yang bisa bertahan lama.

Selain itu, figur elite agama (kiai, tokoh agama) adalah sosok yang mempunyai peran penting dalam mewujudkan harmonisasi kehidupan antar kelompok agama. Dengan sendirinya, terwujudnya harmonisasi kehidupan di Paesan memerlukan energi sosial, yang dalam mengaktualisasikannya memerlukan sinergisitas bersama antara gagasan, ide, dan pemikiran para kiai dengan keseriusan warga untuk ke luar dari persoalan konflik. Pertanyaannya, bagaimana jika kemudian tidak ada lagi tokoh agama (kiai) yang peduli sepeninggal kiai-kiai sepuh di Paesan? Maka yang diperlukan adalah adanya suatu kesadaran warga (collective consciousness) bahwa sesungguhnya antar mereka tidak dapat hidup dalam suasana dan situasi konflik dalam suatu physical boundary. Oleh sebab itu, tidak lagi perlu memperdebatkan perbedaan paham dan ajaran agama. Satu sama lain hendaknya saling patuh (komit) terhadap keputusan dan kesepakatan yang telah dibangun bersama melalui 'perspektif internal' dan masing-masing terus menjunjung tinggi etika-moral menuju pada sebuah kesadaran untuk senantiasa berlomba-lomba berbuat kebaikan (fastabiqul khoirot). 


\section{BIBLIOGRAFI}

Appadurai, Arjun, "Global Ethnoscape: Notes and Queries for Transnational Anthropology”, dalam R.G. Fox (ed.), Recapturing Anthropology, Santa Fee, NM: School of America Research Press, 1991.

Berger, Peter dan Thomas Luckmann, The Social Construction of Reality. New York: Penguin Books, 1979. , Tafsir Sosial atas Kenyataan, Jakarta: LP3ES, 1990.

Bourdieu, Pierre, An Introduction to the Work of Pierre Bourdieu: The Practice Theory, London: The Macmilland Press Ltd., 1990.

Bungin, Burhan (ed), Analisis Data Penelitian Kualitatif: Pemahaman Filosofis dan Metodologis Ke Arah Penguasaan Model Aplikasi, Jakarta: Raja Grasindo Persada, 2003.

Darban, Adabi, Rifaiyah Gerakan Sosial Keagamaan di Pedesaan Jawa Tengah Tahun 1850-1982, Tesis, Yogyakarta: UGM, 1987.

Djamil, Abdul, Perlawanan Kiai Desa, Yogyakarta: LKiS, 2001.

Geertz, Clifford, Tafsir Kebudayaan, Yogyakarta: Kanisius, 1992.

Green, J. W, 1995. Cultural Awarness in the Human Service, Boston: Allyn and Bacon.

Hasbullah, Dasar-Dasar Ilmu Pendidikan, Jakarta: Rajawali Press, 2008.

Kettani, M. Ali, Minoritas Muslim di Dunia Dewasa ini, Jakarta: PT. Raja Grafindo Persada, 2005.

Sanjek, R. (ed.). Fieldnotes: The Makings of Anthropology, Ithaca and London: Cornell University Press, 1990. 
